\title{
Method for Designing Endogenous Runoff Sponge Green Space in the Riverside - A Case Study of the Green Space on the North bank of Yaojiang River in Ningbo
}

\author{
Wang Xiayu ${ }^{1, \mathrm{a}}, \mathrm{Wu}$ wei $^{1, \mathrm{~b}^{*}}$ \\ ${ }^{1}$ Shanghai Institute of Technology \& School of Ecological Technology and Engineering, Shanghai, China
}

\begin{abstract}
The riverside green space is an important ecologically sensitive area which connecting urban space and the river. The traditional landscape design method to create riverside green space can no longer meet the requirements of the concept of an ecological city. In recent years, the spongy city concept that has emerged in China which has provided new research ideas for the landscape design of riverside green spaces. Based on the characteristics of endogenous runoff type riverside green space, this paper takes the sponge system of the green space on the north bank of the Yaojiang River as the research object, analysed it's design strategy, and summarizes the design process and method of the sponge system. The purpose is to provide a reference for the design of the sponge system of the endogenous runoff type riverside green space in the future.
\end{abstract}

\section{Introduction}

On the one hand, due to the rapid increase of urban population and the expansion of the urban fringe, many natural patches have been replaced by artificial impervious surface, which disturbs the rainwater cycle and brings a series of urban water issue ${ }^{1-}$. On the other hand, in order to solve the problem of urban water the sponge city with the core concept of "natural accumulation, natural penetration, and natural purification" was born ${ }^{6-}$. As the urban ecologically sensitive area and popular development and construction area, it is particularly important that the method to solve the water problem in the riverfront.

With the frequent occurrence of urban water problems, more and more scholars are conducting research on sponge cities. Although in recent years, scholars have continuously enriched the theory and practice of the sponge system of waterfront space, nevertheless compared with the regional scale urban sponge city and low-impact development system theories, the riverside area Sponge theory research accounts for a very small proportion ${ }^{9-}$. Therefore, the aim of this paper is to enrich the research content of sponge system in the riverside green space by studying the endogenous runoff type green space sponge system, and promote the design method of the urban riverside space sponge system.

\section{Materials and Methods}

\subsection{Endogenous runoff type riverside green space \\ a528281210@qq.com \\ b* Corresponding author: 429669460@qq.com}

The urban riverside green space is the interface between the land and the river within the urban area. It means the space between the river and the city, including the river's revetment space, green space of riverside or buildings and other areas affected by the river. According to the spatial layout of the riverside area, it can be divided into: the city activity venues of waterfront, the waterfront greening and recreation venues, and the waterside playing venues ${ }^{17}$. The endogenous runoff green space is a type of green space that collects the rainwater resource within the range of the it, and infiltrates, stores, and uses the resource under the conditions of certain rainfall return period ${ }^{1819}$.

The waterfront green space on the north bank of the Yao River is located in the comprehensive flood prevention demonstration area in the old city of $\mathrm{Ningbo}^{20}$. The site is located in a riverside space belt between Yaojiang River and Binjiang Road, about 2500 meters from east to west, 50-100 meters wide from north to south, covering an area of $17.2 \mathrm{hm}^{2}$. There is no rainwater pipe network or interception system pipe network from external areas, and no external rainwater or pollution sources enter the site. Therefore, this is a typical endogenous runoff sponge green space, as shown in Figure 1.

\subsection{Riverside green space characteristics}

\subsubsection{Linear space}

The riverside green space is mostly a continuous longitudinal strip space. It is adjacent to the water and 
the urban. It can stitch the city and the water space and connect the green patches around the site. The unique riverside corridor undertakes ecological and landscape functions.

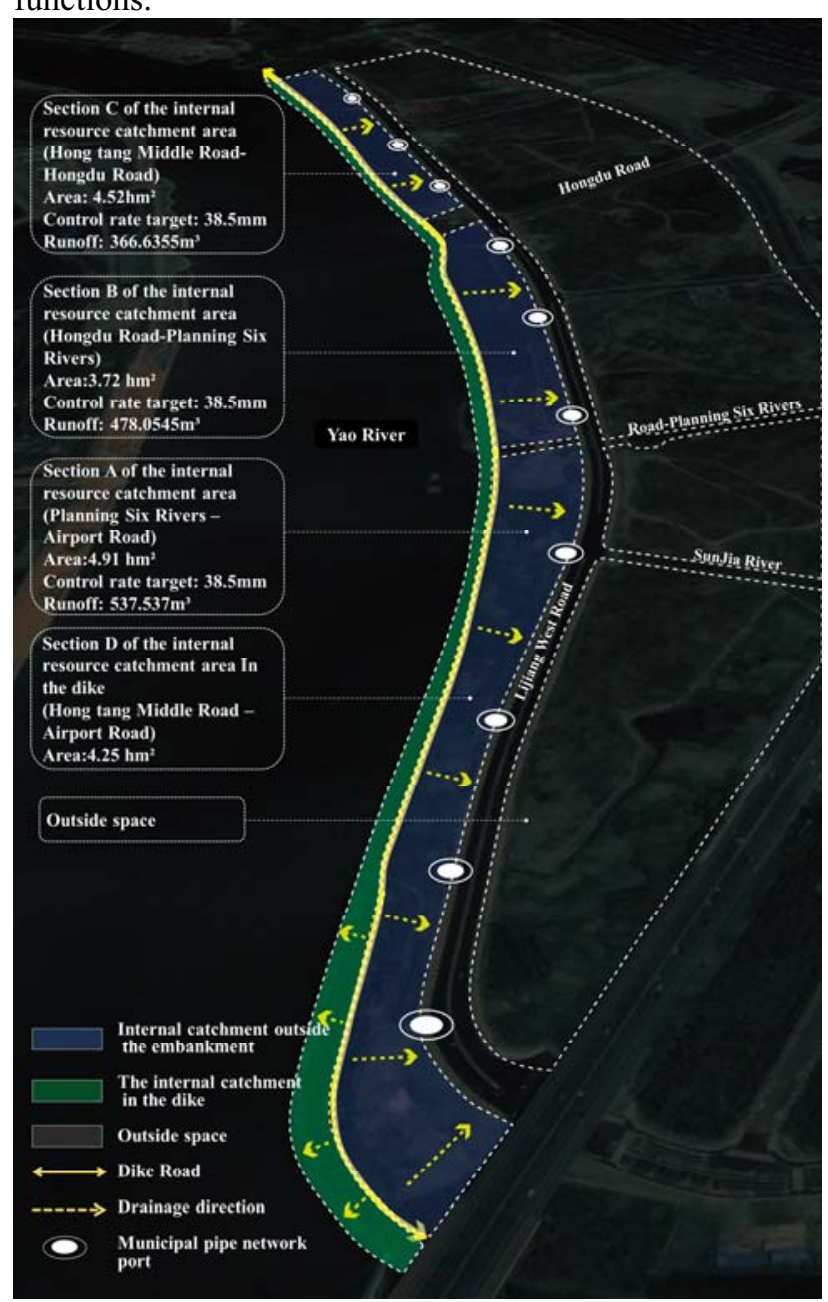

Figure 1. Rainwater runoff source catchment.

\subsubsection{Ecological sensitivity}

The riverfront area is the intersection of two different ecosystems. Though it has extremely high ecological sensitivity and species richness. Human intervention has brought great disturbance to the riverfront area, so the balance between space for human activity and natural habitat is particularly important.

\subsubsection{Historic}

This river is a witness to the history of the city, a place of trade and the birthplace of politics and traditional culture. The riverside area is the business card of the city which occupies the important landscape interface of the city. How to inject historical and cultural elements into the riverside landscape, and showing the vitality and historical background of modern cities, is worthy of indepth thinking.

\section{Results and Discussion}

\subsection{Design strategy of sponge system}

\subsubsection{External space of flood dike}

The external space $\left(12.95 \mathrm{hm}^{2}\right)$ of the flood dike is the main area where rainwater management facilities are arranged. The sponge facilities with three functions of penetration, retention and storage are combined into a sponge system, including: grass swales, Low elevation greenbelt, ecological detention pool, rainwater garden, detention tank, permeable pavement and green roofs. Reinstate the destroyed ecological environment and natural hydrological cycle through the sponge system on the riverside green space.

\subsubsection{Roads and squares}

In order to make full use of the linear spatial structure of the site, three intersecting route systems were created, including the main road on the flood dike, the scenic route by the river and the walking path connecting the scenery code. The five meters wide road on the flood dike is made of permeable asphalt, forming a fitness trail that runs through the entire green space and has the functions of running and cycling; the scenic road by the river uses the river scenery advantages to create a scenic trail. A sidewalk connects a series of activity code with a width of two to three meters, which paved with permeable concrete and permeable bricks to ensure the infiltration of rainwater. The leisure squares adopt a mixed paving method of permeable bricks and ordinary stones, and the sports field and children's activity spaces adopt the form of the permeable concrete to ensure applicable functions and reduce the formation of the rainwater runoff.

\subsubsection{Sponge system}

\section{(1) Grass swales}

It is mainly distributed on the side of the drainage slope of roads and squares, collecting rainwater that did not seep during heavy rain. In addition, on the north side of the research site, grass swales are arranged beside the municipal road, and the overflow pipe is connected to the municipal pipe network. Unlike the two sides of the road, the grass swales on the north with two meters wide and 300 millimeters depth, collects the rainwater runoff from the parking lot, which has a certain degree of pollution. Therefore, various aquatic plants were planted in grass swales which can divert rainwater while purifying rainwater.

(2) Low elevation greenbelt

In the periphery of the building or lawn, the low elevation greenbelt is formed by adjusting the topography of the site. Combined with stones and outdoor theater stage lighting landscape facilities, a low elevation greenbelt is formed, with a depth of about 150 millimeters and an overflow inside. This is also a sunny lawn for parent-child activities and outdoor theaters. When it rains, it is used to regulate and store the 
surrounding rainwater runoff and the runoff introduced by the grass swales.

\section{(3) Rainwater garden}

Utilizing the landscape space and the views, a rainwater garden is built in the depression to regulate, store and purify the surrounding rainwater, and combine the sponge facilities with the landscape space to increase the watching of the sponge facilities. The plants used in the rainwater garden include canna, iris, calamus and other water-tolerant plants, combined with stones, fully embodying the principle of bionic design.

\section{(4) Ecological detention pool}

The ecological retention pool is three to eight meters wide and 500 millimeters deep. The bottom simulates a natural pebble beach, forming a 300 millimeters deep water retention layer. The second layer is planted with moisture-tolerant plants, including iris and calamus. The third layer is planted with the water-tolerant tree, such as Pistacia chinensis, tallow tree, North American red maple, which formed the upper plant space, and the lower plant is planted with Pennisetum and Coreopsis, with natural stones are arranged at the edge of the pond, the sponge facility not only has the function of purifying rainwater, but also a characteristic landscape pond for leisure and viewing.

\section{(5) Green roofs and Detention tanks}

The multiple sets of building in the site form a green roof of about $0.64 \mathrm{hm}^{2}$ to purify rainwater. Rainwater flows through the downpipe and enters the rainwater tank for storage after abandoning the initial rainwater. And the stored rainwater is used for toilet water in the building and plant irrigation.

\subsubsection{Space in the flood dike}

\subsubsection{Riverside scenic road}

A vegetation buffer zone is set between the riverside scenic road and the flood dike to reduce the speed of rainwater runoff, and increase rainwater infiltration. The five meters wide riverside scenic road adopts a staggered paving method of granite and permeable bricks. Eventually, the impermeable rainwater enters the pipe network through rainwater wells and is transported to the grass swales and low elevation greenbelt on the north side of the site.

\subsubsection{Hydrophilic design}

Combined with square landscape, part of the revetment is renovated, stepped revetment, and an internal water area is formed to grow aquatic plants. Due to the limitation of the transportation river, most of the rigid revetment can only be retained. But emergent plants are planted in local rivers to form various revetment habitat spaces and increase the diversity of landscape.

\subsection{Design method of sponge system}

After repeated calculations and inference, the design method of sponge system was finally formed. The details are as follows: To begin with, the design goals and functions of the sponge system are determined by analyzing the rainwater problems and soil characteristics at the design site. Next, use the amount of rainfall to calculate the total adjusted and stored rainwater volume; then use GIS analysis to divide the catchment area of the site; determine the type and scale of sponge facilities according to the adjusted and stored rainwater volume of each catchment area; finally combine the landscape space, optimize the sponge system, and finally form a complete sponge system.

\subsubsection{Design goals of sponge system}

According to the exploration results, the surface coating of the study site is relatively loose, while the permeability of the lower silty clay is poor. Therefore, site soil was improved in the design, and the soil replacement was performed in the sponge facility to ensure soil permeability. According to the characteristics of the endogenous runoff green space, the internal runoff of the space is the control target, combined with the landscape space, to construct a sponge system with the functions of infiltration, retention, storage, purification and reuse. As shown in Figure 2.

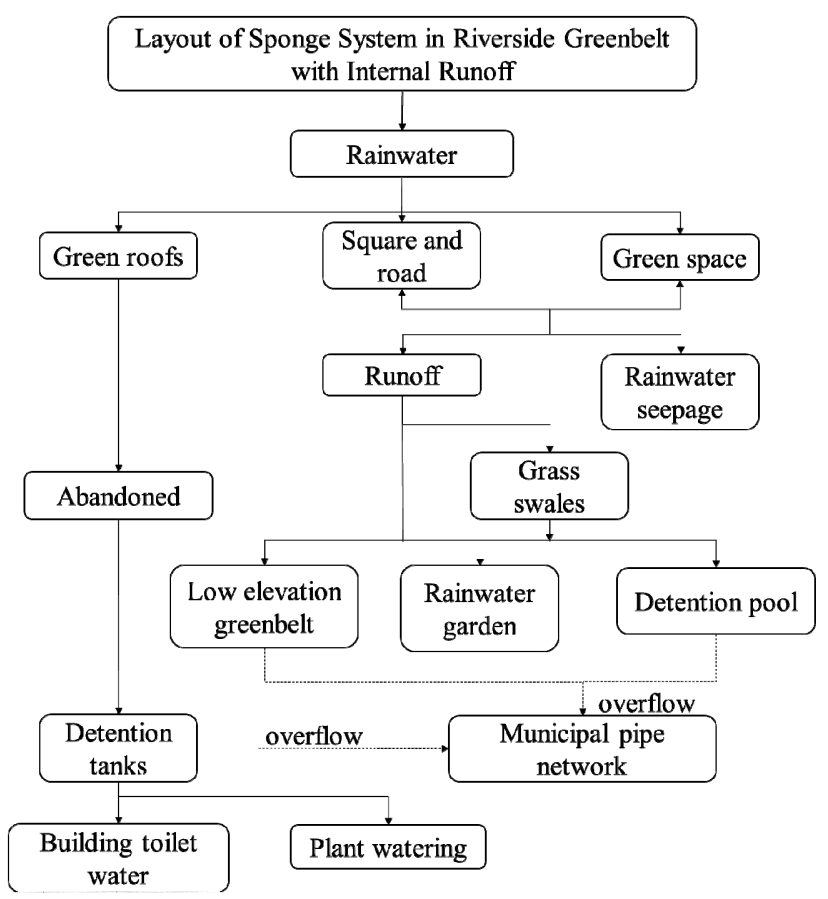

Figure 2. Rainwater runoff flow chart of Green Space.

\subsubsection{Catchment division}

The characteristics of the liner space of the research site have increased the complexity of the space terrain. Therefore, based on the information of site contours, roads, squares and buildings, a site elevation model is constructed based on GIS software, and GIS hydrological analysis tools are used to extract the results of site ponds, urban pipe networks, slope, aspect, etc. 
Realize the division of the catchment area of the site, and finally combine the analysis results with the landscape planning space to adjust, and finally obtain the complete catchment area and surface runoff characteristics, as shown in Figure 3.

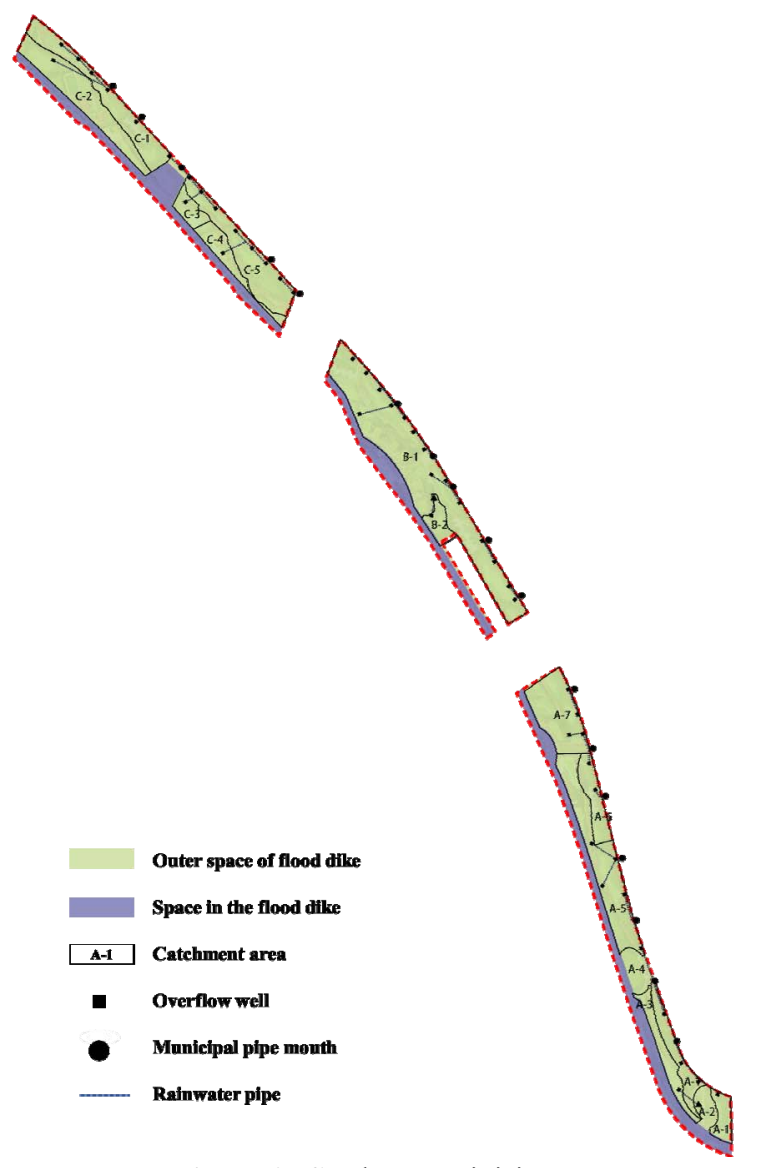

Figure 3. Catchment Division.

\subsubsection{Calculation of storage capacity and Layout of sponge facilities}

Based on the requirements for the total annual runoff control rate of the Yaojiang pilot area in the "Detailed Planning of Ningbo Sponge City Pilot Area" (the total annual runoff control target is $90 \%$, the design rainfall is 38.5 millimeters), according to the different underlying surfaces in the area of each water catchment, runoff coefficient, use the volume method, the flow method, the water balance method and other methods to calculate the runoff required for each catchment area and the scale of different sponge facilities.

The designed storage volume is estimated according to the volume method, as shown in formula $(1)^{21}$ :

$$
V=10 H \varphi F
$$

$\mathrm{V}$ : design storage volume $\left(\mathrm{m}^{3}\right) ; \mathrm{H}$ : design rainfall (millimeter); $\varphi$ : the comprehensive rainfall runoff coefficient; F: catchment area $\left(\mathrm{hm}^{2}\right)$

According to the total annual runoff control target requirements and the design rainfall, the comprehensive runoff coefficient value of each catchment area is calculated. The rainwater runoff of the riverside green space on the north bank of the Yaojiang River is obtained, as shown in Table 1.

The scale of rainwater facilities dominated by infiltration in the research site is determined by volumetric method and infiltration calculation method, as shown in formula $(2)^{22}$ :

$$
V=V_{S}+W_{P}
$$

$\mathrm{V}$ : controllable rainfall volume of the rainwater facility; $\mathrm{V}_{\mathrm{s}}$ : effective storage volume of the infiltration facility $\left(\mathrm{m}^{3}\right) ; \mathrm{W}_{\mathrm{p}}$ : infiltration volume $\left(\mathrm{m}^{3}\right)$

\begin{tabular}{|c|c|c|c|c|c|c|c|}
\hline $\begin{array}{l}\text { Design } \\
\text { rainfall } \\
\mathrm{H} / \mathrm{mm}\end{array}$ & Catchment & & $\begin{array}{c}\text { Catchment area } \\
\qquad \mathrm{F} / \mathrm{hm}^{2}\end{array}$ & $\begin{array}{c}\text { Comprehensive } \\
\text { rainfall runoff } \\
\text { coefficient } \varphi\end{array}$ & $\begin{array}{c}\text { Design storage } \\
\text { volume } \\
\mathrm{V} / \mathrm{m}^{3}\end{array}$ & $\begin{array}{c}\text { storage } \\
\text { volume } \\
\mathrm{V} / \mathrm{m}^{3}\end{array}$ & $\begin{array}{c}\text { Total storage } \\
\text { volume } \\
\mathrm{V} / \mathrm{m}^{3}\end{array}$ \\
\hline \multirow{14}{*}{38.5} & \multirow{7}{*}{$\begin{array}{c}\text { A Sun River - Airport } \\
\text { Road }\end{array}$} & A-1 & 0.8 & 0.17 & 52.36 & \multirow{7}{*}{537.537} & \multirow{14}{*}{1382.227} \\
\hline & & A-2 & 0.27 & 0.4 & 41.58 & & \\
\hline & & A-3 & 0.46 & 0.24 & 42.504 & & \\
\hline & & A-4 & 0.36 & 0.28 & 38.808 & & \\
\hline & & A-5 & 1.49 & 0.34 & 195.041 & & \\
\hline & & A-6 & 0.49 & 0.2 & 37.73 & & \\
\hline & & A-7 & 1.16 & 0.29 & 129.514 & & \\
\hline & \multirow{2}{*}{$\begin{array}{c}\text { B HongDu Road - Sun } \\
\text { River }\end{array}$} & B-1 & 3.64 & 0.33 & 462.462 & \multirow{2}{*}{478.0545} & \\
\hline & & B-2 & 0.27 & 0.15 & 15.5925 & & \\
\hline & \multirow{5}{*}{$\begin{array}{l}\text { C HongTang Road - } \\
\text { HongDu Road }\end{array}$} & $\mathrm{C}-1$ & 1.16 & 0.15 & 66.99 & \multirow{5}{*}{366.6355} & \\
\hline & & $\mathrm{C}-2$ & 1.33 & 0.15 & 76.8075 & & \\
\hline & & C-3 & 1.61 & 0.24 & 148.764 & & \\
\hline & & C-4 & 0.44 & 0.23 & 38.962 & & \\
\hline & & C-5 & 0.38 & 0.24 & 35.112 & & \\
\hline
\end{tabular}

Table 1. Yaojiang North Riverfront green open space designed regulation and storage volume

$\mathrm{K}$ : soil permeability coefficient, with a value of 10-4 $\mathrm{cm} / \mathrm{s} ; \mathrm{J}$ : hydraulic drop slope, with a value of $1 ; \mathrm{A}_{\mathrm{s}}$ : effective infiltration area; ts: infiltration time, with a value of 2 hours.
The scale of each sponge facility on the site is calculated by the above method, as shown in Table 2 .

Table 2. LID facility storage capacity.

Item storage volume Total storage




\begin{tabular}{ccc}
\hline & $/ \mathrm{m}^{3}$ & $\begin{array}{c}\text { volume } \\
/ \mathrm{m}^{3}\end{array}$ \\
\hline Grass swales & 496 & \\
\hline Low elevation greenbelt & 1089.7 & \multirow{2}{*}{2183.7} \\
\hline ecological detention pool & 85 & \\
\hline rainwater garden & 477 & \\
\hline detention tank & 36 &
\end{tabular}

\subsubsection{Optimization of sponge facilities and Landscape treatment}

The research site uses the current soil mounds to transform the terrain, forming a natural rain-harvesting terrain, a better landscape space and views. The layout of the sponge facility is combined with various activity squares, and the low elevation greenbelt is transformed into a multifunctional space by using customized activity modes, which can be used as an outdoor activity venue while collecting rainwater. The activity venue is arranged around the rain garden and combined with the landscape gallery to form a resting place. The bionic design principles of the biological retention pool create educational science and interactive features, as shown in Figure 4.

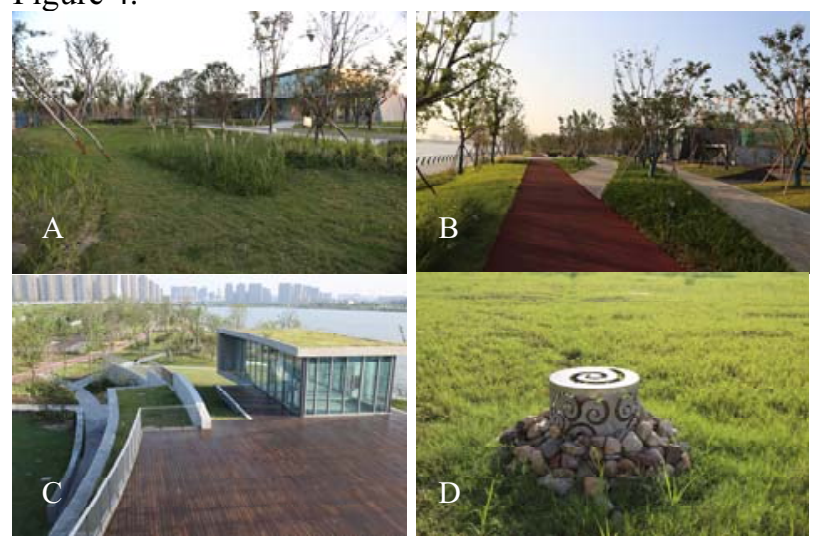

Figure 4. Early construction pictures of Yaojiang North Riverfront green open space. (A: Grass swales; B: Permeable pavement; C: Green roofs; D: Overfall gap)

\section{Conclusion}

Under the background of the concept of ecological, green, harmonious urban, this paper takes the characteristics of endogenous runoff type riverside green space as an entry point, take the sponge system of waterfront green space on the north bank of the Yaojiang River as an example to discuss and summarize the design strategies and design methods, purpose to enrich and promote the design methods and ideas of the urban waterfront green space sponge system without providing reference in the future.

\section{References}

1. Zang, J.Y., Song, X.M., Wang, G.Q., et.al. (2014) Development and challenges of urban hydrology in a changing environment: I: Hydrological response to urbanization. Advances in Water Science, 25: 594-605.

2. Liu, C.M., Zhang, Y.Y., Wang, Z.G. et.al. (2016) The LID Pattern for Maintaining Virtuous Water Cycle in Urbanized Area: A Preliminary Study of Planning and Techniques for Sponge City. Journal of Natural Resources, 31: 719-731.

3. Ran, M.Y. (2000) Discussion on Hydrologic Effect of Urbanization. Journal of Sichuan Normal University (Natural Science), 04: 436-439.

4. Jiao, S., Ma, B., Li, B. (2019) Review on Causes and Control Strategies of Waterlogging in China. Ecological Economy, 35: 92-97.

5. Richard D. UK. (2016) Flood Disasters Affected 2.3 Billion and Killed 157000. http://floodlist.com/dealing-with-floods/flooddisaster-figures-1995-2015.

6. Wu, Z.L. (1987) Preliminary analysis of pollution characteristics of urban runoff in Hangzhou. Shanghai Environmental Sciences, 06: 35-38.

7. Ministry of Housing and Urban-Rural Development of the People's Republic of China. (2014) Sponge City Construction Technical Guide-Low-impact development rainwater system construction. China Architecture \& Building Press, Beijing.

8. Fei, W.J., Ding, J.Y., Cao, Y. (2018) Applicability Design in Waterfront Green Space from "Flood Discharge Ditch" to "Sponge Garden". Chinese Landscape Architecture, 34: 106-111.

9. Jain, A., Kumar A. (2006) An evaluation of artificial neural network technique for the determination of infiltration model parameters. Applied soft computing, 6: 272-282.

10. Yu K. (2011) Qunli National Urban Wetland-A stormwater park for a water resilient city. Topos European Landscape Magazine.

11. Sun, Z. (2019) Research on Waterfront Landscape Reconstruction Design Based on Sponge City Concept_-Taking Shanghai Shipyard Green Space Project as an Example. Construction Materials \& Decoration, 11: 78-79.

12. Liu, R.J. (2018) Research on waterfront landscape design under the concept of sponge city. Xiandai Horticulture, 04:118-119.

13. Xu, D.L., Zhou, X.L., Wang, Y.Y. (2017) Planning and design of waterfront renewal based on the concept of "ecological sponge city"___ Taking the renewal of Shenyang 204 old district as an example. Housing and Real Estate, 36: 73.

14. Chen, J.X. (2016) Construction and Application Result of Grassed Swales in Shijiazhuang Waterfront Ecological Park. The Journal of Hebei Forestry Science and Technology, 06: 1-4.

15. Yao, Y. (2020) Analysis on the Urban Waterfront Landscape Design under the Sponge City Construction Concept-Taking the Phase I Project 
of Ningbo Yongjiang Waterfront Park as an Example. Xiandai Horticulture, 43: 68-69.

16. Han, T., Lu, J.W. (2020) Analysis of waterfront landscape design based on the concept of sponge city. Xiandai Horticulture, 43: 126-127.

17. Wu, J.Q., He, M. (1998) Analysis on the Planning Mode of Urban Waterfront Space. City Planning Review, 02: 46-49.

18. Li, Z.Y., Huo, R., Ge, X.Y. (2020) Research on the Design Method of Endogenousrainwater Runoff Rainwater-harvesting Green Space in Sub -humid Area_-Taking Shehuo Park in Jinzhong, Shanxi Provinvee as the Example. Chinese Landscape Architecture, 36: 107-112.

19. Kang, J.Q., Ge, X.Y. (2019) Method for Designing Exogenous Runoff Sponge Green Space in Semihumid Region-A Case Study of the Green Space of East Binhu Road in Qian'an City. Landscape Architecture, 26: 77-82.

20. Wang, S.S., Yang, K., Che, W. (2019) Green rainwater infrastructure in sponge city construction. China Architecture \& Building Press, Beijing.

21. Ministry of Construction of the People's Republic of China.(2013) Technical Code for Rainwater Utilization Engineering in Buildings and Residential Districts: GB50400-2006. China Architecture \& Building Press, Beijing.

22. Zhenjiang City Planning and Design Institute. (2019) Sponge City Planning and Design Case Collection. China Architecture \& Building Press, Beijing. 